Nervenarzt 2019 $\cdot 90: 71-72$

https://doi.org/10.1007/s00115-018-0631-0

Online publiziert: 9. Oktober 2018

(c) Springer Medizin Verlag $\mathrm{GmbH}$, ein Teil von Springer Nature 2018

CrossMark
M. Belz · M. Besse · L. Krech · I. Methfessel · D. Zilles

Klinik für Psychiatrie und Psychotherapie, Station 4193, Universitätsmedizin Göttingen, Göttingen, Deutschland

\section{Erratum zu: Wirksamkeit und Verträglichkeit der Elektrokonvulsionstherapie}

\section{Einfluss des klinischen Ansprechens aus Patientensicht}

\section{Abstract}

\section{Erratum zu:}

\section{Nervenarzt 2018}

https://doi.org/10.1007/s00115-018-

0604-3

Durch eine fehlerhafte Bearbeitung des englischen Abstracts während des $\mathrm{Pu}$ blikationsprozesses wird eine Korrektur notwendig. Das korrigierte und vollständige Abstract ist diesem Erratum zu entnehmen.

Wir bitten, diesen Fehler zu entschuldigen. Der Originalbeitrag wurde korrigiert.

\section{Korrespondenzadresse}

\section{Dr. rer. nat. M. Belz}

Klinik für Psychiatrie und Psychotherapie, Station 4193, Universitätsmedizin Göttingen v. Siebold-Str. 3, 37075 Göttingen, Deutschland mbelz1@gwdg.de

Nervenarzt https://doi.org/10.1007/s00115-018-0631-0

(c) Springer Medizin Verlag GmbH, ein Teil von Springer Nature 2018

M. Belz $\cdot$ M. Besse $\cdot$ L. Krech $\cdot$ I. Methfessel $\cdot$ D. Zilles

Erratum to: Effectiveness and tolerability of electroconvulsive therapy. Influence of clinical response from the patient's point of view
Abstract

Background. Electroconvulsive therapy (ECT) is a highly effective, yet still controversial therapy for both the general public and psychiatrists. In this study, we investigated the patients' view regarding effectiveness and tolerability of electroconvulsive therapy under consideration of individual clinical response.

Material and methods. In 31 patients with major depression, subjective effectiveness and tolerability were assessed via a differentiated questionnaire prior to, during, and after ECT. Symptoms were rated using the Montgomery-Åsberg depression rating scale (MADRS) and the Beck depression inventory II (BDI-II)
Results. Patients assessed ECT to be generally effective both before and after the treatment. This view was independent of their individual treatment success. In contrast, patients' rating of individual effectiveness depended on the objective improvement of their symptoms. Side effects were rated to be generally slight to moderate.

Conclusion. Against the background of persisting criticism towards ECT, the viewpoint of involved patients provides us with important references for an appropriate judgement of this therapy. The results suggest a good benefit-risk ratio for ECT from the patients' perspective. 
Hier steht eine Anzeige.

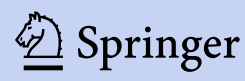

